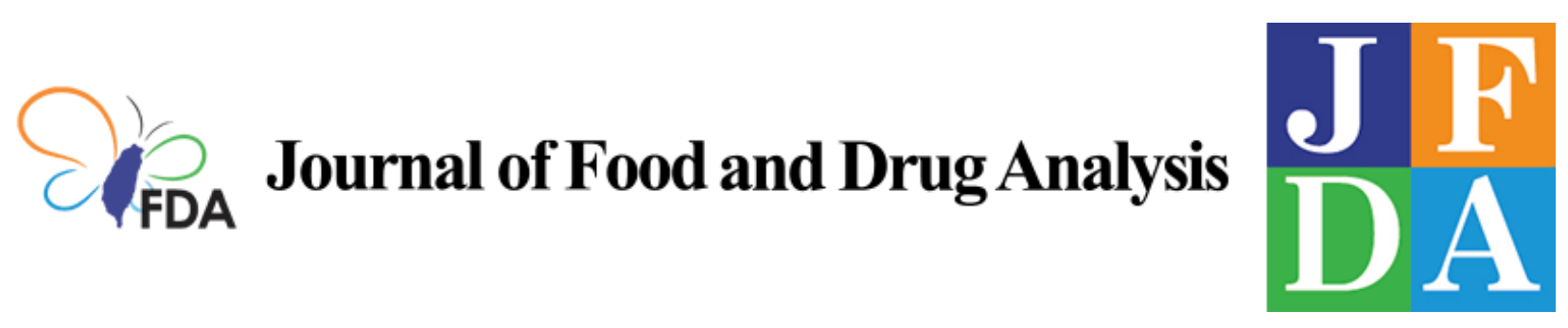

Volume 1 | Issue 4

Article 2

1993

\title{
The Application of Capillary Electrophoresis in Analysis of Chinese-Herb Drugs
}

Follow this and additional works at: https://www.jfda-online.com/journal

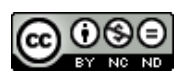

This work is licensed under a Creative Commons Attribution-Noncommercial-No Derivative Works 4.0 License.

\section{Recommended Citation}

Liu, Ying-Mei and Sheu, Shuenn-Jyi (1993) "The Application of Capillary Electrophoresis in Analysis of Chinese-Herb Drugs," Journal of Food and Drug Analysis: Vol. 1 : Iss. 4 , Article 2.

Available at: https://doi.org/10.38212/2224-6614.3069

This Original Article is brought to you for free and open access by Journal of Food and Drug Analysis. It has been accepted for inclusion in Journal of Food and Drug Analysis by an authorized editor of Journal of Food and Drug Analysis. 


\title{
毛細管電泳在中藥分析上的應用
}

\author{
劉英玫＼cjkstart許順吉 \\ 國立臺灣師範大學化學研究所
}

\begin{abstract}
摘 要
毛細管電泳(Capillary Electrophoresis, CE) 是新近發展出來的一種分析方法, 已廣泛應用 於蛋白質、胺基酸、核苷酸、有機酸、䒚物等的分離分析,效果良好。CE分析時間短、再現性佳、自 動取栐, 尤其特別適合於分析高極性物質的特性,應可有效地應用於中䒚成分的定量。本文介紹 其在莐菜、黄檗、黄連、麻黄、黄芩等中菜材, 及含麻黄、含黄連、含黄檗、含黄芩、含甘草、含杏仁

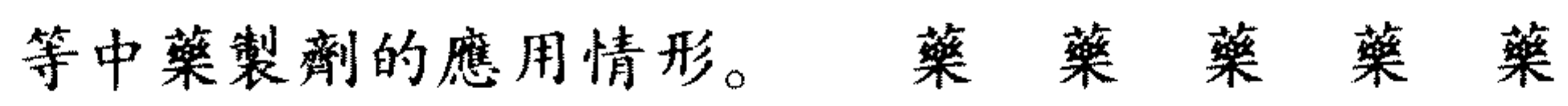

\section{前言}

中藥材因基源、產地、栽培方法、生長環境、採 收季節及加工處理過程的不同, 往往在品質上有很 大的差異,傳統上以外觀制斷品質之優劣, 缺乏科 學數據評估, 常有誤謬。自中藥製劑預定列入公勞 保給付後,民衆接受中藥治病的觀念更临普遍, 篇 求公正客觀,應有一套快捷、便利、準確、又嚴謹的 品質評估方法。

目前分析中藥以高效能液相層析法(HPLC)最 爲理想, 但中藥製贸組成成分複雜, 用HPLC分析 常存有許多變數和困難, 諸如: (a)分離管柱的個別 差異一不同慜牌的同一材質管桂,或同一儌牌的不 同批次產品, 都可能存在若干差異, 分析過程中若 改換一支管柱, 可能得到前後不完全一致的圖譜; (b)管柱常因試劑的破壞或雜質的殘留導致性能持 續衰退一中藥成分繁多, 分析時不易顧及所有成分 的特性, 導致若干成分的殘留, 清洗不易, 加上分析 高極性物質時所用緩衝溶液的添加劑常會損及逆 相管柱的填充物, 因此雖裝置保護管桂並勤加淸洗 亦常見管柱性能迅速衰退; (c) 分析時間長一中藥 製劑從低極性到高極性成分衆多,一般分離清洗時 間甚長, 當作日常品管分析工具效率很受影響; (d) 自動化限制多一不同樣品使用不同管柱不同沖提 液, 尤其改換溶媒、清洗管桂, 很難在短時間內完成
, 自動化執行不易; (e)分析成本高一管柱及溶劑費 用高。因此, 尋找新的分析方法, 提供多元化資料, 極爲必要。

毛細管電泳(capillary electrophoresis，CE) 是 近年來新發展的分析方法, 對離子性或高極性化合 物有非常良好的分離分析效果, 它具有分析時間短 , 樣品和沖提液用量少, 使用內徑25-100 um的毛 細管價格低廉, 中空管柱清洗容易換液迅速, 採自 動化注射等優點, 是甚具發展潛力的分析工具。中 藥的生物畧、配醣體、有機酸、酚類等常節製劑的主 要藥理活性成分, 也是水煎煮時的主要抽提物, 這 些高極性物質是評估中藥品質的重點所在,但也正 是用HPLC 分析時較會產生困擾的部份, 已有的 資料顯示 CE 在這方面會成爲一個很好的分析方 法。

\section{毛細管電泳}

電泳是電介質中帶電粒子在電場作用下以不 同速度向電荷相反的電極方向移動的現象, 利用這 種現象對某些化學成分進行分離分析的技術,稱爲 電泳技術。

電泳作爲一種分析工具出現,已有近百年的歷 史,但眞正被視爲有重要意義的技術, 則是在1937 年由瑞典科學家Arene Tiselius (1)首先提出的, 後 來, Tiselius等人利用這技術從人的血淸中成功地 
分離出白蛋白、 $\alpha$ 球蛋白、 $\beta$ 球蛋白和 $\gamma$ 球蛋白, 由於 Tiselius對電泳技術發展和應用的傑出貢獻, 使他 成爲1948年諾貝爾化學獎的得主。

傳統電泳最大的問題是難以克服由兩端的高 電壓所引起的電介質離子流的自熱, 或稱焦耳熱, 這種焦耳熱會引起載板從中心到兩側或管子內徑 向的粘度梯度和速度梯度, 導致區帶展寬, 降低效 率, 這種影響會隨電場強度的增加而迅速加劇, 因 此大大的限制了高電壓的使用, 當然也就難以加快 整個過程的速度。毛細管電泳和傳統電泳的最大區 別,就在於前者設法使電泳過程在散熱效率極高的 毛細管內進行, 所以可引入高的電場強度, 全面改 善分離效果。

1967年Hjerten ${ }^{(2)}$ 首先提出在高電場, 直徑爲3 $\mathrm{mm}$ 的毛細管中作自由溶液的區帶電泳(capillary zone electrophoresis, CZE)。1974 年 Virtenen ${ }^{\left({ }^{3}\right)}$ 提 出用200-500 $\mu \mathrm{m}$ 內徑的毛細管作電泳分離。而在 目前所談及的那種細管徑毛細管內實現電泳的最 初工作是由Jorgenson 和Lukacs ${ }^{(4,5)}$ 在1981年首 先提出的,當時,他們使用了75 um內徑的玻璃毛 細管柱, 用螢光檢測器作線上(on-line)檢測, 同時 他們還就分離的原理、高電場和小內徑對高效的決 定性影響等問題進行了討論。1984年Terabe ${ }^{(6)}$ 等 人引入了毛細管電泳的一個重要分離模式, 即以各 組成成分 (特別是中性粒子) 在毛細管內的膠束和 緩衝液之間的分配篇基礎的膠束電動力學毛細管 層析 (micellar electrokinetic capillary chromatography,MECC or MEKC)。1987年Hjerten (7)把 傳統的等電聚焦過程移到毛細管內進行, 提出毛細 管等電聚焦(capillary isoelectric focusing, CIEF) 分析方法。同年,Cohen 和Karger ${ }^{(8)}$ 發表了毛細管 凝膠電泳(capillary gel electrophoresis, CGE)論文 。1988年, Rose 和Jorgenson (9)首先探討利用毛細 管電泳作微量製備的可行性, 並提取了50微微莫耳 的蛋白質和胜肽。

和傳統的電泳相比,毛細管電泳最主要的特點 有三: 一是高效能, 二是快速, 三是微量。在毛細管 區帶電泳中,柱效一般爲每米幾十萬理論板數, 高 的可達每米百萬以上,而在凝膠電泳中這一指標竟 能達到幾百萬甚至上千萬。商品儀器的操作皆自動 化,通常的分析時間不超過30分鐘,在探用電流檢 測器時, 毛細管電泳的最低檢測極限可達 $10^{-19}$ 莫耳 , 而即使是一般的紫外光檢測器, 大體也在 $10^{-13}-$ $10^{-15}$ 莫耳之間,樣品用量僅爲納升 $(\mathrm{nl})$ 而已。

毛細管電泳和高效能液相層析(HPLC)同屬液 相分離技術, 它們遵循不同的分離機理,都有許多
的分離模式,因此在很大程度上CE 與HPLC 呈現 互補,但無論從效率、速度、樣品用量和成本各方面 來看, 毛細管電泳都顯示了一定的優勢。與HPLC 相比, 毛細管電泳的柱效更高, 速度更快, 同時, 它 幾乎不消耗溶劑, 而樣品用量僅爲HPLC的幾百分 之一, $\mathrm{CE}$ 沒有原輸送系統, 因此成本相對要低, 改 變操作模式和緩衝液的成份, 毛細管電泳有很大 的選擇性, 可以根據不同的分子性質（諸如大小、電 荷數、疏水性等)對極廣泛的對象進行有效的分離, 相比之下, 爲達到類似的目的, HPLC要消耗許多 價格昂貴的管柱和溶劑。

CE那具有特色的扁平流型(flat flow profile) 是導致毛細管高效的重要原因。而HPLC中由壓力 控制的流型則呈抛物線型, 流體移動速度不一, 導 致吸收峰變寬, 理論上流型限制了HPLC的分離效 率。

另一方面,HPLC已發展有許多的固定相和移 動相可供分離時選擇。以此觀點, CE相對上是較少 發展的工具。在儀器方面, HPLC 和CE在某些觀 點相似但彼此不同, CE較簡單, 因爲沒有注射器、 洜、特定的偵測槽等。在HPLC中, 樣品是用注射器 注入, 注入溶液的體積可算得很精確; 而CE並沒有 如HPLC的注射閥, 樣品溶液通常用電驅動或重力 (壓力) 的方式注入, 注射量較難計算, 定量時一定 要加內標準品。

HPLC 和 CE 的偵測方式類似, 許多早先爲 HPLC開發的偵測器, 諸如UV、螢光、電化學、導電 度、Raman和放射線同位素偵測器,也適於 $\mathrm{CE}$ 的 偵測。在光學偵測技術中, 如UV偵測器, HPLC的 濃度靈敏度要比CE好 ${ }^{(10)}$, 這是因爲 CE的槽徑長 (毛細管寬度)通常小於傳統的HPLC的槽徑長的 關係。爲彌補這方面的缺憾,各種不同的偵測方法 正陸續開發中, 例如 CE由雷射誘導螢光(11.12)和電 化學偵測 (13.14) 就有極靈敏的檢測效果, 偵測極限 可達attomole ( $10^{-18}$ 莫耳) 以下。

\section{毛細管電泳在定量分析上的應用}

雖然毛細管電泳的實際分析應用僅是最近幾 年的事, 但各雜誌上已出現了相當大量的論文,應 用的範圍也很廣泛,包括: 利用導電度偵測分析無 機陰離子及有機酸根離子(15.16); 用電滲流修飾劑 得到帶正電的管壁後進行果汁中有機酸的分析 (17) ; 以phenylthiohydantoin衍生物(18)和ortho-phthaldiadehyde衍生物(19)分析胺基酸; 用於內臟荷爾蒙 motilin的定量 (20) 及各種抗原胜肽類的分析 ${ }^{(21)}$; 用 
MECC 分離核苷酸衍生物 ${ }^{(22)}$, 用 coating管柱分離 ribonucleoside triphosphate (NTP) 和 deoxyribonucleoside triphosphate $(\mathrm{dNTP})^{(23)}$; 多氯芳香烴 ${ }^{(24)}$ 及多環芳香烴 ${ }^{(25)}$ 的分析; 用 gradient 方式增加 2propanol和Triton X-100濃度以分離4-nitrobenz2-oxa-1,3-diazole (NBD) 衍生的胺類 ${ }^{(26)}$; 血漿中 aspoxicillin的定量 ${ }^{(27)}$, 以 CE/MS 分析四種benzodiazepines ${ }^{(28)}$, 及藥物antihistamines的分析 ${ }^{(29)}$; 用 酸性磷酸監溶液分離 maltooligosaccharide的pyridylamino(PA) 衍生物 ${ }^{(30)}$, 配合不同濃度的borate 緩衝液分離各種醣類(31); 用於分析具有不同數量 carboxylate或sulfate官能基之聚合物乳液粒子(32), 分析聚合物中作爲plasticizer的phthalates ${ }^{(33)}$; 及天 然物Uncaria tomentosa中六個oxindole生物鹼之 分析 ${ }^{(3)}$ )等。

\section{毛細管電泳在中藥分析上的應用}

中藥用水煎煮,所得萃取液主要含高極性物質 ,其藥效成分尤以生物鿥、配醣體、有機酸等最爲普 遍。1990年Honda ${ }^{(35)}$ 等人最早將CE應用於苟藥之 藥效成分 paeoniflorin和oxypaeoniflorin的定量, 發 現CE再現性佳,定量結果與HPLC近似。

黃菜的主要藥理活性成分有berberine、 palmatine、 jatrorrhizine、和phellodendrine, 黃連則爲berberine , palmatine , coptisine , epiberberine , jatrorrhizine 、 columbamine 、 berberastine 和 magnoflorine, 均爲四級銨鹽, 本身已帶一個正電荷, 但 因粒子之質量差異不大, 需要選擇一個適當的配對 離子(counter ion), 利用它與氮作用力之不同, 使 各粒子之淨正電荷出現差異, 造成移動速度不同, 並在緩衝溶液中加入有機溶劑(甲醇或咨甲烷) 當 修飾劑, 以減少毛細管壁的負電對正電離子的吸附 ,如此就可得到較陡峭的吸收峰。

黃萻藥材檢液以 $0.5 \mathrm{M}$ 醋酸鈵溶液和 $50 \%$ 的氧 甲烷分析,在八分鐘內可將各生物撂有效分離(36); 而黃連藥材檢液則在 $0.1 \mathrm{M}$ 醋酸鈵溶液和 $15 \%$ 的甲 醇下,於十三分鐘內順利完成八種生物畧的分析 (37)。分析大量樣品, 發現市售川連及雅連之品質優 於日連及日連變種植物, 日連無 berberastine 和 epiberberine, 日連變種無berberastine及僅含微量 的epiberberine, 極易辨識(38), 魏氏黃藮和日本黃莧 之品質優於關黃䓝和川黃䓝菜, 另berberine是黃藍各 藥材中含量最多的成分, 約佔魏氏黃葟、日本黃㮐 總生物䣓含量的 $80 \%$,但只佔關黃萻、川黃蓝的 40 $\%(39)$, 顯示一般僅由berberine含量評估黃葟品質,
或值得再檢討。

麻黃藥材中的ephedrine 和pseudoephedrine 爲二級胺, methylephedrine和 methylpseudoephedrine䈆三級胺, norephedrine和norpseudoephedrine爲一級胺, 若使用酸性緩衝溶液,均能使它們帶 正電, 但三對非鏡像異構物(diastereomer)間則無 法分離,所以利用有光學活性之胺基酸與之結合, 再配合鋇離子使具有不同之移動速度, 可在十分鐘 內達到分離之目的(40)。各麻黃藥材都以ephedrine 和pseudoephedrine含量最多, 草麻黃、木賊麻黃、 雙穗麻黃之ephedrine均多於pseudoephedrine,中 麻黃的pseudoephedrine鹞ephedrine的三倍有餘; 一般草麻黃優於中麻黃( ${ }^{(4)}$ 。

黃芩之六個黃酮類成分(三個配醣體baicalin、 wogonin 7-0-glucuronide、 oroxylin A 7-0-glucuronide 和它們的水解物 baicalein 、wogonin 、 oroxylin A)則是另一種類型, 它們可在鹼性條件 下可變成陰離子,但三個非醣體之差異太小,所以 在虐衝溶液中加入十二烷基硫酸鈉(sodium dodecyl sulphate, SDS), 並調整pH值, 使它們與SDS的 互溶程度出現差異,達到分離之目的(42)。

用 $0.01 \mathrm{M}$ valine 和氨水配成的緩衝溶液可分 析十九種含麻黃製劑之 ephedrine 和 pseudoephedrine 含量, 其回收率在98.0-102.3\% 之間, 相 對標準偏差是 $0.86-0.87 \%$, 每次分析時間約三分鐘 (43)。用 $50 \%$ 的 $0.2 \mathrm{M}$ 醋酸鈉溶液和 $50 \%$ 的氯甲烷可 在八分鐘內分別分析二十三種含黃連黃菜製劑之 coptisine、berberine和palmatine, 其回收率在 98.0 $101.9 \%$ 之間, 相對標準偏差是 0.96-1.50\% (intra-

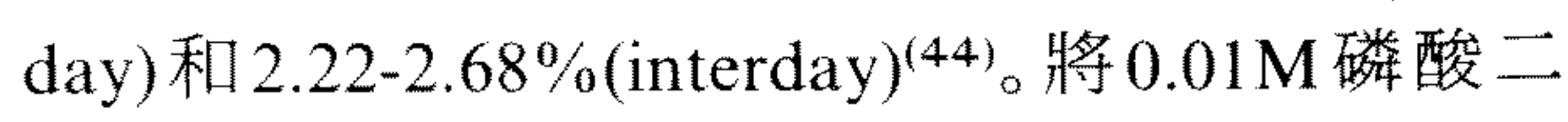
氫鈵、0.0125M焦性硼酸鈵(sodium borate, $\mathrm{Na}_{2} \mathrm{~B}_{4}$ $\left.\mathrm{O}_{7}\right)$ 和 $0.02 \mathrm{M} \mathrm{SDS}$ 溶液混合可分析九種含黃芩製劑 中的四個黃酮類成分 (baicalin 、 baicalein、wogonin 7-0-glucuronide、和wogonin), 各成分之回收率 在98.1-102\%之間,相對標準偏差是0.88- $2.42 \%{ }^{(45)}$ 。

甘草是近牛數中藥製劑的組成藥材, 其所含 glycyrrhizin爲主要藥效成分, 已知該化合物使用 過量可能產生一些副作用,因此一般規定爲必須定 量的成分。用 $\mathrm{pH} 7.5$ 的磷酸二氫鈵爲緩衝溶液, 加 上修飾劑氯甲烷, 可在十分鐘內精確地計算glycyrrhetinic acid 和 glycyrrhizin 之含量, 其回收率 在98.1-101.4\%之間,相對標準偏差是glycyrrgizin $1.02 \%$,glycyrrhetinic acid $0.91 \%{ }^{(46)}$ 。苦杏仁苷 (amygdalin)是杏仁、桃仁的主要藥理活性成分, 也 是評估含杏仁製劑品質的指標物質,這類製劑用 HPLC分析時極易造成管柱的污染, 用焦性研酸鈉 
和SDS配成的緩衝溶液分析十三種含杏仁的製劑， 除在十四分鐘內可順利完成外, 並有很好的回收率 (98.2-100.1\%)及再現性 (相對標準偏差 intraday $1.29 \%$,interday $1.55 \%)^{(47)}$ 。

綜合已知資料發現利用CE分析各種中藥製劑 , 結果要比HPLC好, 因爲CE的選擇性高, 對製劑 中其它成分的干擾, 可藉緩衝溶液之選擇予以排除 , 且毛細管之清洗容易, 一般清洗只需兩分鐘, 若要 更換毛細管也相當方便, 只要規格相同, 任何一支 毛細管均可得到相同結果。基於 CE分析時間短、再 現性佳、可自動化等特性, 推測其應非常適宜大量 品管之用。

\section{參考文獻}

1.Tiselius, A.1937.A new apparatus for electrophoretic analysis of colloidal mixtures .Trans. Faraday Soc. 33 : 524-531.

2.Hjerten, S. 1967. Free zone electrophoresis. Chromatogr. Rev. 9 : 122-129.

3.Virtenen, R. 1974. Zone electrophoresis in a narrow-bore tube employing potentiometric detection. Theoretical and experimental study . Acta Polytech. Scand.123 : 1-67.

4.Jorgenson, J. W. and Lukacs, K. D. 1981. Zone electro-phoresis in open-tubular glass capillaries. Anal. Chem. 53 : 1298-1302.

5.Jorgenson, J.W. and Lukacs, K.D. 1983. Capillary zone electrophoresis. Science. 222 : 266-272.

6.Terabe, S., Otsuka, K., Ichikawa, K.,Tsuchiya, A. and Ando, T. 1984. Electrokinetic separations with micellar solutions and opentubular capillaries. Anal. Chem. 56 : 111-113.

7.Hjerten, S., Liao, J. L. and Yao, K.1987. Theoretical and experimental study of highperformance electrophoretic mobilization of isoelectrically focused protein zones. J. Chromatogr.387 : 127-138.

8.Cohen, A. S. and Karger, B. L. 1987. Highperformance sodium dodecyl sulfate polyacrylamide gel capillary electrophoresis of peptides and proteins. J. Chromatogr. 397 : 409-417.

9.Rose, D.J. and Jorgenson, J.W. 1988. Characterization and automation of sample intro- duction methods for capillary zone electrophoresis. Anal. Chem. 60 : 642-648.

10.Steuer, W., Grant, I. and Erni, F. 1990.Comparison of high-performance liquid chromatography, supercritical fluid chromatography and capillary zone eletrophoresis in drug analysis. J. Chromatogr.507 : 125-140.

11. Wu, S. and Dovichi, N.J. 1989. High-sensitivity fluorescence detector for fluorescein isothiocyanate derivatives of amino acids separated by capillary zone electrophoresis. J. Chromatogr.480 : 141-155.

12. Cheng, Y.F. and Dovichi, N.J. 1989. Subattomole amino acid analysis by capillary zone electrophoresis and Laser-induced fluorescence.f Science. 242 : 562-564.

13. Wallingford, R. A. and Ewing, A. G. 1988. Capillary zone electrophoresis with electrochemical detection in 12.7 um diameter columns. Anal. Chem. 60 : 1972-1975.

14. Wallingford, R. A. and Ewing, A. G. 1989. Separation of serotonin from catechols by capillary zone electrophoresis with electrochemical detection. Anal. Chem. $61: 98-100$.

15. Beckers, J. L., Verheggen, Th. P. E. M. and Everaerts, F. M. 1988. Use of a double-detector system for the measurement of mobilities in zone electrophoresis. J. Chromatogr. 452: 591-600.

16. Romano, J., Jadik, P., Jones, W.R. and Jackson, P.E. 1991. Optimization of inorganic capillary electrophoresis for the analysis of anionic solutes in real samples. J. Chromatogr. $546: 411-421$.

17. Kenney, B.F. 1991. Determination of organic acids in food samples by capillary electrophoresis. J. Chromatogr. $546:$ 423-430.

18. Liu, J., Cobb, K.A. and Novotny, M. 1988. Separation of precolumn ortho-phthaladehyde-derivatized amino acids by capillary zone electrophoresis with normal and micellar solutions in the presence of organic modifiers. $\mathbf{J}$ . Chromatogr. 468 : 55-65.

19. Albin, M., Weinberger, R., Sapp, E. And Moring, S.1991. Fluorescence detection in capillary electrophoresis : evaluation of derivati- 
zing reagents and techviques. Anal. Chem. 63 : 417-422.

20.Florance, J.R., Konteatis, Z.D., Macielag, M. J., Lessor, R.A. and Galdes, A. 1991. Capillary zone electrophoresis studies of motilin peptides. Effects of charge, hydrophobicity, secondary structure and length. J. Chromatogr. $559:$ 391-399.

21.Pessi, A., Bianchi, E., Chiappinelli, L., Nardi, A. and Fanali, S. 1991. Application of capillary zone electrophoresis to the characterization of multiple antigen peptides. J. Chromatogr. $557:$ 307-313.

22.Row, K.H., Griest, W.H. and Maskarinec, M .P. 1987. Separation of modified nucleic acid constituents by micellar electrokinetic capillary chromatography. J. Chromatogr. $409: 193$ -203 .

23. Takigiku, R. and Schneider, R.E. 1991. Reproducibility and quantitation of separation for ribonucleoside trophosphates and deoxytibonucleoside triphosphates by capillary zone electrophoresis. J. Chromatogr. 559 : 247-256.

24.Terabe, S., Miyashita, Y., Shibata, O., Barnhart, E.R., Alexandrer, L.R., Patterson, D. G., Karger, B.L., Hosoya, K. and Tanaka, N 1990. Separation of highly hydrophobic compounds by cyclodextrin-modified micellar electrokinetic chromatography. J. Chromatogr. $516: 23-31$.

25.Bruin, G.J.M., Tock, P.P.H., Kraak, J.C. and Poppe, H. 1990. Electrically driven open-tubular liquid chromatography. J. Chromatogr. 517 : 557-572.

26. Balchunas, A.T. and Sepaniak, M.J. 1988. Gradient elution for micellar electrokinetic capillary chromatography. Anal. Chem. 60 : 617-621.

27. Nishi, H., Fukuyama, T. and Matsuo, M. 1990. Separation and determination of aspoxicillin in human plasma by micellar electrokinetic chromatography with direct sample injection. J. Chromatogr. $515:$ 245-255.

28. Johansson, I.M., Pavelka, R. and Henion, J. D. 1991. Determination of small drug molecules by capillary electrophoresis-atmospheric pressure ionization mass spectrometry. $\mathrm{J}$. Chromatogr. 559 : 515-528.

29.Ong, C.P., Ng, C.L., Lee, H.K. and Li, S.F.Y 1991. Determination of antihistamines in pharmaceuticals by capillary electrophoresis. J. Chromatogr. $588:$ 335-339.

30. Nashabeh, W. and Rassi, Z.E. 1990. Capillary zone electrophoresis of pyridylamino derivatives of maltooligosaccharides. J. Chromatogr. 514 : 57-64.

31. Amankwa, L.N. and Kugr, W.G. 1991. Indirect fluorescence detection in micellar electrokinetic chromatography. Anal. Chem. 63 : 1733-1777.

32. Amankwa, L.N., Scholl, J. and Kuhr, W.G. 1990. Characterization of the oligomeric dispersion of poly(oxyalkylene)diamine polymers by percolumn derivatization and capillary zone electrophoresis with fluorescence detection. Anal. Chem. $62: 2189-2193$.

33.Ong, C.P., Lee, H.K. and Li, S.F.Y. 1991. Separation of phthalates by micellar electrokinetic chromatography. J. Chromatogr. 542 : 473-481.

34.Stuppner, H., Sturm, S. and Konwalinka, G. 1992. Capillary electrophoretic analysis of oxindole alkaloids from Uncaria tomentosa. $\mathbf{J}$ . Chromatogr. $609:$ 375-380.

35.Honda, S., Suzuki, K., Kataoka, M., Makino , A. and Kakehi, K. 1990. Analysis of the components of Paeonia radix by capillary zone electrophoresis. J. Chromatogr. 515 : 653-658.

36. Liu, Y.M. and Sheu, S.J. 1993. Determination of quaternaty alkaloids from Phellodendri Cortex by capillary electrophoresis. J. Chromatogr. 634 : 329-333.

37. Liu, Y.M. and Sheu, S.J. 1992. Determination of quaternary alkaloids from Coptidis Rhizoma by capillary electrophoresis. J. Chromatogr. 623 : 196-199.

38. Liu, Y.M., Sheu, S.J., Chiou, S.H., Chang, H .C. and Cheu, Y.P. 1993. Capillary electrophoretic analyses of alkaloids on commercial samples of Coptidis Rhizoma. submitted to Phytochemical Analysis. 
39.Liu, Y.M., Sheu, S.J., Chiou, S.H., Chang, H .C. and Cheu, Y.P. 1993. A comparative study on commercial samples of Phellodendri Cortex. Planta Medica. in perss.

40. Liu, Y.M. and Sheu, S.J. 1992. Determination of ephedrine alkaloids by capillary electrophoresis. J. Chromatogr. $600:$ 370-372.

41.Liu, Y.M., Sheu, S.J., Chiou, S.H., Chang, H .C. and Cheu, Y.P. 1993. A comparative study on commercial samples of Ephedrae Herba. Planta Medica. 59 : 376-378.

42. Liu, Y.M. and Sheu, S.J. 1993. Determination of the six major flavonoids in Scutellariae Radix by micellar electrokinetic capillary electrophoresis. Anal. Chim. Acta. in press.

43. Liu, Y.M. and Sheu, S.J. 1993. Determination of ephedrine and pseudoephedrine in Chinese herbal perparations by capillary electrophoresis. J. Chromatogr. 637 : 219-223.
44.Liu, Y.M. and Sheu, S.J. 1993. Determination of coptisine, berberine and palmatine in traditional Chinese medicinal perparations by capillary electrophoresis. J. Chromatogr. 639 : 323-328.

45. Liu, Y.M. and Sheu, S.J. 1993. Determination of baicalein, baicalin, wogonin and wogonin 7-0-glucuronide in traditional Chinese medicinal perparations by capillary electrophoresis, submitted to HRC.

46. Chen, H.R. and Sheu, S.J. 1993. Determination of glycyrrhizin and glycyrrhetinic acid in traditional Chinese medicinal preparations by capillary electrophoresis. J. Chromatogr. 653 : 184-188.

47.Lu, C.F. and Sheu, S.J. 1993. Determination of amygdalin in traditional Chinese medicinal perparations by capillary electrophoresis. Chin. Pharm. J. in press. 


\title{
The Application of Capillary Electrophoresis in Analysis of Chinese-Herb Drugs
}

\author{
YING-MEI LIU AND SHUENN-JYI SHEU
}

National Taiwan Normal University

\begin{abstract}
Capillary electrophoresis (CE) is a newly developed instrument widely used with very good results in the analysis and separation of proteins, amino acids, peptides, organic acids as well as pharmaceuticals. It offers short analysis times, good reproducibility, autosampling, and is especially suitable for the analysis of high polar compounds. These characteristics lead to conjecture about possible application to analysis of

Chinese herbal drugs. This paper describes the use of capillary electrophoresis in analysis of such crude drugs as Paeoniae Radix, Phellodendri Cortex, Coptidis Rhizoma, Ephedrae Herba , Scutellariae Radix and the Ephedrae Herbacontaining, Coptidis Rhizoma-containing, Phellodendri Cortex-containing, Scutellariae Radix-containing, Glycyrrhizae Radix-containing, Armeniacae Semen-containing Preparations.
\end{abstract}

Key words : Capillary Electrophoresis, Chinese-Herb Drugs, Chinese-Herb Preparations. 
